\title{
Effect of pesticides on human health
}

\section{Bapayeva Gauri. ${ }^{1}$, Kulbayeva Saltatnat ${ }^{2}$, Zhumadilova Akmaral. $^{3}$}

${ }^{1}$ Department of obstetrics and gynecology, National research center for maternal and child health of the corporate fund «UMC», Astana, Kazakhstan

${ }^{2}$ South Kazakhstan State Pharmaceutical Academy, Shymkent, Kazakhstan

${ }^{3}$ Akhmet Yassawi International Kazakh-Turkish University

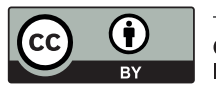

This work is licensed under a Creative Commons Attribution 4.0 International License

J CLIN MED KAZ 2017; 3(45 SUPPL 3):128-132 Corresponding author: Бапаева Г.Б., отдел акушерства и гинекологии, Национальный научный центр материнства и детства корпоративного фонда «University Medical Center». Адрес: ул.Туран 32, Астана, Казахстан. Телефон: 8-7172-70-44-72,

E-mail: gauri.bapayeva@gmail.com

\section{ABSTRACT}

Pesticides are unique chemicals, that deliberately spread in the environment and their toxicity has limited selectivity species. The Republic of Kazakhstan is a region where cotton is one of the most important sectors of agricultural production and textile industry, which in recent decades is experienced a new rise. Women are made up the largest part among the workers of this industry, which is concentrated in the south. For a long time in the cotton industry have been widely used organochlorine pesticides. The article presents a literature review of the effect of organochlorine pesticides on the human health, including the reproductive system.

Keywords: pesticides, reproductivehealth, human.

\section{ТҰЖЫРЫМДАМА}

ПЕСТИЦИДТЕРДІН АДАМ ДЕНСАУЛЫҒЫНА ӘСЕРІ

\section{Бапаева Г.Б¹, Кулбаева С.Н², Жумадилова А.P³.}

${ }^{1}$ Акушерлік және гинекология бөлімі, «UMC» корпоративтік қорының Ана мен бала ұлттық ғылыми орталығы, Астана, Қазақстан

${ }^{2}$ Оңтүстік-қазақстан мемлекеттік фарацевтика академиясы, Шымкент, Қазақстан

${ }^{3}$ Қ. А. Ясауи атындағы Халықаралық қазак-түрік университет

Пестицидтер өзінің әсер етуі жағынан қауіпті химикаттар болып табыла отырып қоршаған ортада кең көлемде тарап отыр, олардың токсикалық әсерінің түрі шектелген таңдауда. Қазақстан Республикасы мақта егуде соңғы он жылдықта қайта өркендеп келе жатқан ауыл шаруашылығы және текстильдік мата өндірісінің маңызды саласы болып табылады. Еліміздің оңтүстігінде бағытталған осы саладағы жұмыс жасайтындардың едәуір бөлігін әйел тұрғындары құрайды. Көптеген жылдар бойына мақта өндірісінде хлорорганикалық пестицидтер кеңінен қолданылған. Мақалада хлорорганикалық пестицидтердің адам ағзасына әсері, соның ішінде репродуктивті денсаулыққа әсері туралы әдеби шолу жасалынған.

Маңызды сөздер: хлорорганикалық пестицидтер, репродуктивті денсаулық.

\section{PEЗЮME}

\section{ВЛИЯНИЕ ПЕСТИЦИДОВ НА ЗДОРОВЬЕ ЧЕЛОВЕКА}

Бапаева Г.Б. ${ }^{1}$, Кулбаева С.Н. ${ }^{2}$, Жумадилова А.P. ${ }^{3}$

${ }^{1}$ Отдел акушерства и гинекологии, Национальный научный центр материнства и детства корпоративного фонда «UMC», г. Астана, Казахстан

${ }^{2}$ Южно-казахстанская государственная фармацевтическая академия, г. Шымкент, Казахстан ${ }^{3}$ Казахско-Турецкий Университет им. Х.А. Ясави

Пестициды являются уникальными химикатами, токсичными по своему действию, сознательно распространяются в окружающую среду, и их токсичность имеет ограниченную избирательность видов. Республика Казахстан является регионом, где хлопководство является одной из важнейших отраслей сельскохозяйственного производства и текстильной промышленности, которая в последние десятилетия испытывает новый подъем. Женское население составляют наибольший удельный вес среди работников данной отрасли, которая сосредоточена на юге страны. На протяжении длительного времени в хлопковой промышленности широко использовались хлорорганические пестициды. В статье предствален литературный обзор влияние хлорорганических пестицидов на организм человека, в частности,на репродуктивную систему.

Ключевые слова: пестициды,репродуктивное здоровье, человек.

\section{Kiрicne}

Пестицидтердің адам денсаулығына, ең алдымен репродуктивті жүйеге әсерін зерттеу мәселесі өзекті болып қала бермек, өйткені соңғы он жылда пестицидтерді қолдану 4 есе жоғарыдан асып отыр [1].

Бүгінгі таңда өте аз концентрациясында токсикалық заттар болып табылатын пестицидтер тұрақты органикалық ластаушылар тобына кіреді. Өзінің жасушалар кеңісітігінде орын алу қасиетімен адам ағзасына анағұрлым қауіп туғызатын, иммунды және репродуктивті жүйелер ауруларын, балаларда тума ақаулар, онкологиялық аурулармен жүретін көптеген патологиялық жағдайлармен үдерістердің себептері болып табылады [2-7]. Тникалық ластаушылар (ТОЛ) зияндылығы дамып жатқан ұрпаққа плацента арқылы, ал нәрестеге емшек сүті арқылы өтеді [89]. 
ТОЛ-дың адам десаулығына аса жағымсыз әсеріне байланысты Стокгольм конвенциясы қабылданды (2001 жылдың 22 мамыры) және 2004 жылдың 17 мамырынан бастап күшіне енді. Стокгольм конвенциясына сәйкес қолдануға алдымен құрамында хлоры бар органикалық 12 заттарға (альдрин, дильдрин, хлордан, эндрин, мирекс, гептахлор, гексахлорбензол, токсафен, ДДТ); өндірістік химиялық заттар (полихлорленген бифенилдер) және жанама өнімдер (полихлордибензодиоксиндер және полихлордибензофурандар) тиым салынды. Стокгольм конвенциясын қолдаушыларының төртінші Конференциясында (2009 ж. 4-8 мамыр) тізімдегі он екі ТОЛға жаңадан 9 зат қосты: хлордекон, пентахлорбензол, линдан, альфа-гексахлорциклогексан, бета-гексахлорциклогексан, гексабромбифенил, пентабромдифенил эфир, октабромдифенил эфир, перфтороктандысульфонат [10].

Құрамында хлоры бар органикалық пестицидтер: альдрин, дильдрин, хлордан, эндрин, мирекс, гептахлор, гексахлорбензол, токсафен, ДДТ 2002 ж. Стокгольм конвенциясы бойынша тыйым салынған «ластанған дюжинаға» кірді.

Пестицидтер адам ағазасына барлық белгілі тәсілдермен: тері жабындылары, асқазан-ішек трактісі және тыныс алу жолдары арқылы кіреді. Алғашқы екі жол ауыл-шаруашылығы және пестицидтер өндіретін кәсіпорын жұмысшыларына тән.

Зерттеулерде биологиялық индикаторлар параметрлері және кейбір хлорорганикалық қосылыстардың токсикалық әсері арасында маңызды корреляциялық байланыс анықталған [11,12]. Альдрин және дильдриннің әсерінен пайда болған зақымдану, олардың қандағы деңгейі 200 мг/л жоғарылағанда көрініс беретіні мәлім. Қандағы линдан концентрациясының 20 мг/л болуы критикалық деңгейден жоғарылағанын көрсетеді және невралгия симптомдары айқындала бастайды. Қандағы эндрин концентрациясының 50 мг/л төмен болуында ешқандай негативті әсерлер байқалмаған.

Эндриннің қайталамалы әсерінде анти-12гидроксиэндринның зәрде концентрациясы 130 мг/г төмен креатиннің және ДДТ қайталамалы әсерінде қан сарысуындағы концентрациясы 250 мг/л төмен болуында ерте негативті әсері болмаған (бауырдың микросомальды ферменттерінің белсенуі) [13-17].

Қазіргі кезде сыртқы ортадағы зиянды факторлардың арасынан репродуктивті токсиндер деп аталатын топты және ең алдымен гормонтәрізді ксенобиотиктерді (ГТК) бөліп шығарады. Оларға: ДДТ және оның метаболиттері, дильдрин, гептахлор, тамоксифен, гексахлоран, метоксихлор, фосфорорганикалық қосындылар қатары және т.б. пестицидтерді кіргізеді. Осы ГТК, әсіресе хлорорганикалық қосындылар тобына кіретіндерге химиялық, физикалық және фото деградацияға жоғары тұрақтылық тән. Олар үлкен қашықтықтарға су және ауа массасымен тарала отырып онжылдар бойына қоршаған ортада сақталынады. Сонымен қатар, оларды ешқашан өндірмеген және қолданбаған жерлерде, мысалы Арктикада, жануарлар мен адам ағзасында табады [18].

ГТК қабілеттілігі адамның репродуктивті үдерісіне «араласуы», жыныс стероидтарының арнайыланған рецепторларымен байланыса алатындығында және табиғи жыныс гормондар түрінде «жасырынуында» болып табылады. Соңғысының, стероидты гормондар сияқты, көптеген ГТК химиялық құрылымы жағынан фенолдар немесе құрамында «фенол эквиваленттерінің» болуымен байланысты $[19,20]$. Эндогенді гормондардың әсерін жаңғырта, шектей немесе өзгерте отырып ГТК репродуктивті функцияның қалыптасу механизміне әсер етуі мүмкін, сондықтан оларды эндокринді деструкторлар деп атайды. Айтылғандарға сүйене отырып, Жер биосферасында гормонтәрізді ксенобиотиктердің пайда болуы ғаламдағы «экологиялық жағдайды» түбегейлі өзгертті деп нақтылауға болады [21-23].

Көптеген ГТК эстрогенді және антиандрогенді әсері бар екендігін атап өту қажет.

R. Sharpe и N. Skakkeback [24] пікірлері бойынша осы заманғы адам «эстрогендердің виртуалді теңізінде өмір сүруде». Сондықтан, қоршаған ортада эстрогенді және антиандрогенді әсер ету қасиеті бар ГТК «жүгінің» көбеюі ерлер ағзасынадада көрінісін тапты. Қазіргі ерлердің репродуктивті жүйесінің «жүдеу» белгілерінің пайда болуы, эякулят мөлшерінің және ондағы сперматозоидтар концентрациясының үдемелі азаюы, соған сәйкес «ерлер» бедеулігінің жиілігінің жоғарылауы мүмкін осымен байланысты деп түсіндірі-леді [25-27].

ГТК әйелдің репродуктивті жүйесіне әсеріне қатысты айтсақ, зиянды факторлардың әйел ағзасына арнайылық әсері басымырақ полиморфтылыққа тән екендігін атап өткен жөн. Бұл қалыптасу механизмі әртүрлілігімен және репродуктивті функцияның іске асырылуымен, ең алдымен репродуктивті үдерістің қатаң циклдылығымен және оның гипоталамус-гипофиз-аналық бездері жүйесінің барлық звенолар жағдайының тәуелділігімен байланысты [28,29].

ГТК әйел ағзасының түрлі-түрлі тіндеріне ену қабілеті бар екендігі анықталған. Цервикалді шырышта, аналық бездерінің фолликулярлы сұйықтығында, емшек сүтінде және амниотикалық сұйықтықта ДДТ, ДДЭ, гептахлор, хлордан, гексахлорбензол, ПХБ, дильдрин, карбоматтар және т.б. сияқты улы химикаттар табылған [30,31].

Көптеген токсиканттарда плацентарлы барьерден өту қабілеті бар екендігі айқындалған. О.В. Долгих авторлармен бірге [32] берген мәліметтері бойынша хлорланған көмірсутегімен $(2,4-Д)$ үнемі байланыста болған жұмысшы әйелдерде, олардың ана қанындағы мөлшерінен ұрықтағы концентрациясы 2, ал плацентада 3 есе жоғары болған.

Мал шаруашылығы фермасының жұмысшы әйелдерінде (зиянды факторлар: құрамында пестицидтер мен микроорганизмдері бар шаң) және көкөніс өсірушілерде (негізгі зияндылық: ауылшаруашылық улы химикаттар) 50\% етеккір циклының бұзылысы (ЕЦБ), оның ішінде жиірек лютеинді фазаның жетіспеушілігі (ЛФЖ) тіркелген [33]. Авторлар, аталған өндірістегі әйелдерде аналық бездеріндегі стероидогенездің бәсеңдеуін репродуктивті қызметті реттейтін орталық механизмнің зақымдалуымен байланысты деп санайды. Сонымен бірге, 5 жылдан аспайтын жұмыс істеген әйелдерде, фолликуланың өсуін, аналық жыныс жасушасының жетілуін және овуляцияның жүзеге асырылуын қамтамасыз ететін гипоталамусгипофиз-аналық бездері жүйесінің резервті мүмкіндігі сақталынған. Жұмыс өтілі 5 жылдан көп әйелдерде, ЕЦБ және овуляторлы функцияның бұзылысы, фертильділіктің бедеулікке дейінгі бұзылысы, жыныс жүйесі мүшелерінде гиперпластикалық үдерістердің дамуымен қосарланған, гипоталамус нейрондарының эстрогендерге, ал аналық бездерінің гонадотропты ынталандыруға сезімталдығының төмендеуімен жүрген.

Н.И. Бескровная авторлармен бірге [22, б. 23- 
46], зиянды әсерлерге әйелдің репродуктивті жүйесінің реакциясында айқын кезеңділікті және бұл реакцияның зиянды фактордың сипатына тәуелсіздігін түсіндірген, оларды зиянды химиялық агенттерге репродуктивті жүйенің бейарнамалы бейімділігі деп қарастырады. Көрсетілген репродуктивті жүйе реакциясының кезеңділігі Г. Сельемен баяндалған жалпы бейімділік синдромы аясына жақсы қойылатын-дығын байқау қиын емес.

Қоршаған ортаның зиянды агенттерінің әсеріне бейімділік механизмі алдымен гипоталамдық-гипофизарлы және адреналды жүйелер деңгейінде дамыған үдерістермен байланысты. В.Н. Серов және А.А. Кожинға [34] сәйкес, әртүрлі табиғатты күйзелістер, соның ішінде «химиялық күйзеліс», эндокринді қалыптасудағы гипоталамдықгипофизарлы жүйенің шектен тыс қозуына нейроэндокринді дисфункцияға: гонадотропиндер секрециясының күшеюіне, эстрогендер өндірілуінің артуына, бүйрекүсті және қалқанша бездерінің гиперфункциясына («экологиялықгенеративті диссонанс») алып келеді. Дамыған эндокринді жылжулар гипоталамус қозуын басуға бағытталған. Оның «тым аса қозуы» зиянды фактордың әсерін жойғанда немесе «физиологиялық емес тәртіп» жұмысына ауысқанда тоқтауы мүмкін.

Органогенез кезеңінде ГТК әсері фундаменталді үдерістерде тіндердің саралануын қамтамасыз етуге: жасушалардың пролиферациясы, миграциясы және ассоциациясы әсері жолымен жүзеге асады. Бұның нәтижесі болып ұрықтың жыныс жүйесінің және бас миының нейроэндокринді орталықтары, сонымен қатар басқада мүшелердің қалыптасуының бұзылысы болуы мүмкін. Сонымен, ресей зерттеушілерінің (2005 жыл) нәтижесі бойынша, тума даму ақауларының (ТДА) жиілігі, әсіресе өнеркәсібі аса дамыған аумақтарда және «пестицидті жүктемесі» қарқынды ауылшаруашылықты аудандарда жоғары болған. Зерттеушілермен соңғы 10-жылдық кезеңде Саратов облысында [35] ТДА 7-есеге (!) өскендігі байқалған.

Осыған ұқсас мәліметтер Өзбекстаның гексахлоранмен үнемі жанаста болған ауылдық тұрғындар әулетін зерттегенде де алынды [36]. Курскіде 1992-2002 жж. кезеңінде ақаулар жиілігі 1,5 есеге артқан [37].

Зақымдаушы факторларға басымырақ «әлсіз» әйел жыныс жасушалары, адамдар мен көптеген сүтқоректілердегі гаметогенездің қорытынды кезеңіне сәйкес келетін жыныстық циклдың периовуляторлы кезеңінде тұрады [38-40]. Бұл бұзылыста байқалатын механизмді басқаратын, ооциттер және овуляция жетілу үдерісінің десинхронизациясы болуы мүмкін. Осы мәліметтерді есепке алғанда, жыныстық циклдың периовуляторлы кезеңін онтогенездің қиын кезеңінің бірі деп қарастыруға болады. Тәжірибелік жағдайда оны ерекше «қорғау» қажеттілігін және осы уақытта жүктілікті жоспарлап жатқан әйелге репродуктивті токсиканттармен байланысты болдырмауды болжайды.
Пренаталды кезеңде ГТК әсерін талдағанда трансплацентарлы канцерогенез мәселесін айрықша бөлу қажет. Тератогендік әсері бар агенттер, органогенез аяқталғаннан кейін ұрыққа әсер еткенде ұрпақта ісіктерге, соның ішінде - репродуктивті жүйенің қатерлі ісігіне ынталандыруы мүмкін екендігі мәлім. Әлемдік статистикаға сәйкес, XX ғасырдың екінші жартысында қатерлі ісіктер саны балаларда анағұрлым өскен. Сонымен, АҚШ Ұлттық регистрі мәліметі бойынша, XX ғасырдың соңында 5-14 жастағы балалар арасында өлім-жітім себебінен қатерлі ісіктер екінші орынға шыққан [41].

Пестицидтердің репродуктивті жүйеге әсеріне қатысты көптеген зерттеулер, көбінесе ересек кезеңде жағымсыз әсерін зерттеу бойынша, сонымен қатар антенаталды кезеңде, балалық шақ кезеңінде, азырақ жеткіншектік кезеңде жүргізілген [42-46].

Жасөспірім кезеңіндегі зерттеулер көп жағдайда ДДТ және оның метаболиті dichlorodiphenyl dichloroethane (DDE) әсерін зерттеуге қатысты болған [47]. Сонымен, жүргізілген зерттеулерде [48-50], ДДТ және оның метаболиттерінің әсері ерте менархе және телархемен ассоциирленетіндігі көрсетілген. Мичиганда (АҚШ) 151 әйелден құралған топта [51], жатырында ДДЕ деңгейінің $15 \mu \mathrm{g} / \mathrm{L}$ дейін жоғарылауы менархенің орташа жасын 1 жылға қысқарғандығы анықталған. Осыған қарамастан, дененің орташа салмағы менархе жасына және ДДЕ деңгейімен байланысы болмашы болған.

Мерзімінен бұрын жыныстық жетілуге тенденция немесе ерте менархе алаңдаушылық туғызады, өйткені мерзімінен бұрын жетілу ересек жастағы кезеңде эндокрин тәуелді жағдайдың дамуына қауіп факторы болып табылады [52].

Зерттеушілер [53] қыздардың мерзімінен ерте жыныстық жетілуін хлорорганикалық пестицидтердің эстрогентәрізді әсері қабілетімен байланыстырады. Осы екі арада, басқа зерттеушілер пестицидтер мен ерте жыныстық жетілу үдерісі арасындағы байланысты таппаған [54]. Сонымен қатар, пестицидтер деңгейінің жоғарылауы стероидты гормондардың төмендеуімен қосарлануын дәлелдейтін де мәліметтер бар. Етеккір циклының периовуляторлы және лютеинді фазаларына сәйкес қандағы ДДЕ деңгейі эстрадиол $(\mathrm{p}=0,03)$ және прогестерон деңгейлерімен $\quad(p=0,03)$ корреляциялық байланыста болғандығы анықталған [55].

\section{Қорытынды}

Осыған байланысты, пестицидтердің пубертатты кезеңнің ағымына әсері туралы зерттеушілердің мәліметтері қайшы болғандықтан, ары қарай қыздар-болашақ аналар ағзасына патологиялық үдерістердің таралу механизмін нақтылау үшін, олардың жағымсыз әсері бойынша зерттеу жүргізу қызығушылық туғызады. Бұл үдерістердің бағытын білу, мүмкін болатын бұзылыстарды дер кезінде анықтау және алдын-алу шараларын құрастыруға көмектеседі.

\section{Литература:}

1. Mnif W., Hassine AI., Bouaziz A., Bartegi A., Thomas O., Roig B. Effect of endocrine disruptor pesticides. Int J Environ Res Public Health. 2011; 8:2265-2303.

2. Aripova T.U., Sirota A.R., Batyrbekov A.A. Immunitet i immunokorektsiya pri pestitsidnykh intoksikatsiyakh (Immunity and immunocorrection in pesticidal intoxications) [in Russian]. Tashkent. 2007. 272.

3. Babushkina N.P. Ekologiyagoroda I zdorov'edetei (Ecology of the city and children's health) [in Russian]. M.: MeditsinaZdorov'e; 2005; T.2. 259 p.

4. Belyaev E.N. Stoikieorganicheskiezagryazniteli, soderzhashchiesya v okruzhayushcheisrede, ikhvliyanienazdorov'enaseleniya 
(Persistent organic pollutants contained in the environment, their impact on human health) [in Russian]. EkologicheskiivestnikRossii. 2002;8:10-15.

5. Kul'baeva K.Zh. Ginekologiya detskogo i podrostkovogo vozrasta (Gynecology of children and adolescence) [in Russian]. Almaty: Evero. 2014. 276 p.

6. Salazar-Garcia F., Gallardo-Diaz E., Ceron-Mireles P. et al. Reproductive effects of occupational DDT exposure among male malaria control workers. Environ. HealthPersp. 2004; 112:542-547.

7. GichevYu.P. Zdorov'e cheloveka kak indicator ekologi i riska industrial'nykh regionov (Human health as an indicator of the ecology of the risk of industrial regions). Vestnik RAMN. 2005; 8: 52-54.

8. Sergeev O.V., Shelepchikov A.A., Denisova T.A. idr. Pilotnoe issledovanie soderzhaniya stoikikh zagryaznitelei v grudnom moloke zhenshchin Chapaevska (Pilot study of persistent contaminants in breast milk of Chapaevsk women) [in Russian]. Vestnik. Ros. VMA. 2008; 3:124-125.

9. Krauthaker B., Reiner E., and Votava-Raii A. et al. Organochlorine pesticides and PCB in human milk collected from mothers nursing hospitalized children. Chemosphere. 2004; 37: 27-32.

10. Stokgol'mskaya konventsiya o stoikikh organicheskikh zagryaznitelyakh (Stockholm convention on persistent organic pollutants) [in Russian]. 2001; http://dokipedia.ru

11. Hauser R., Chen Z., Pothier L. et al. The relationship between human semen parameters and environmental exposure to PCB and p, p1-DDE. Environ. Health Persp. 2003; 111: 1505-1511.

12. Milosevic-Djordjevic O., Grujicic D., Arsenijevic S., Brkic M., Ugrinovic S., Marinkovic D. Micronuclei in cord blood lymphocytes as a biomarker of transplacental exposure to environmental pollutants. Tohoku J Exp Med. 2007; 3(213); $231-239$.

13. Gerunov T.V., Red'kinYu.V.,Gerunova L.K. Immunotoksichnost' pestitsidov: rol' v patologiizhivotnykh I cheloveka (Immunotoxicity of pesticides: a role in the pathology of animals and humans) [in Russian]. Uspekhsovremennoibiologii 2011; 1: 474-482.

14. Ivanenko N.V. Ekologicheskaya toksikologiya (Environmental toxicology) [in Russian]. http://abc.vvsu.ru/Books/ecolog_ tocsicolog/page0008.asp

15. Anne Williford, Kathryn J. DePaolis. Identifying Predictors of Instrumental and Reactive Aggression Among Low-Income Minority Adolescent Girls. Journal of the Society for Social Work and Research. 2012; 3 (3): 145-161.

16. Jarrell J., Villenenve D., Franklin C. et al. Contamination of human ovarian follicular fluid and serum by chlorinated organic compounds in three Canadian cities. J. Can. Med. Assoc. 2003; 148: 1321-1327.

17. Knowledge on Reproductive Health Issues among the Unmarried Adolescent Girls/ NasreenAktherandet. al. Journal of Family and Reproductive Health. 2012; 6(4); 69-176.

18. Fedorov L.A. Dioksiny kak ekologicheskaya opasnost': retrospektiva i perspektivy (Dioxins as an environmental hazard: a retrospective and perspective) [in Russian]. M.: Nauka; 2003. 266 p.

19. Ema M. and Miyawaki E. Adverse effects on development of the reproductive system in male offspring of rats given monobutyl phthalate, a metabolite of dibutyl phthalate, during late pregnancy. Reprod. Toxicol. 2001; 15: 189-194.

20. Gray L.E., Ostby J.S., Ferrell J.M. et al. A dose-response analysis of methoxychlor-induced alterations of reproductive development and function in the rat. Fund. Appl. Toxicol. 2006; 12: 92-108.

21. Baranov A.N., Lebedeva T.B. Mediko-ekologicheskie aspekty fizicheskogo i polovogo razvitiya (Medico-ecological aspects of physical and sexual development) [in Russian]. Zhurnal akusherstvaizhenskikhboleznei.2005; 1: 52-56.

22. Beskrovnaya N.I., Balasanyan I.G., Khrustaleva G.F., Svechnikova F.A. Tezisy № 31. Endokrinnaya sistema organizma i vrednye faktory vneshnei sredy (Endocrine system of the body and harmful environmental factors) [in Russian]. L.; 2003.113 p.

23. Deng F., Tao F.B., Liu D.Y., Xu Y.Y., Hao J.H., Sun Y., et al. Effects of growth environments and two environmental endocrine disruptors on children with idiopathic precocious puberty. Eur J Endocrinol. 2012; 166: 803-809.

24. Sharpe R.H. and Skakkeback N.E. Are estrogens involved in falling sperm counts and disorders of the male reproductive tract? Lancet. 2005; 341: 1392-1395.

25. Nikitin A.I. Gormonopodobnyeksenobiotiki I reproduktivnaya Sistema (Hormon-like xenobiotics And Reproductive System) [in Russian]..Probl. reproduktsii. 2002; 2: 5-15.

26. NikolaevA.A. Vozdeistvietekhnogennykhpollyutantovnaspermatoge-nez(The impact of technogenic pollutants on spermatogonia) [in Russian]. VestnikRos. VMA. 2008; 3:105.

27. Khokhlov P.P., Mikhnina E.A., Kalinina N.M. Znachenie immunofermentnogo opredeleniya autoantitel dlya diagnostiki zabolevaniir eproduktivnoi funktsii (The importance of immune-enzyme determination of autoantibodies for the diagnosis of reproductive diseases) [in Russian]. Rossiskiizhurnalimmunologii. 2007; 4: 144-145.

28. GafarovaD.Kh. Sostoyanie immunnoi sistemy devochek-podrostkov s zaderzhkoi fizicheskogo i polovogo razvitiya (The state of the immune system of adolescent girls with a delay and physical and sexual development)[in Russian]. Zhurnalteoreticheskoi iklinicheskoimeditsiny.2007; 2: 49-51.

29. Kozlova I.G. Immunologiya reproduktsii: teoreticheskie i klinicheskie aspekty (Immunology of reproduction: theoretical and clinical aspects)[in Russian]. Sankt-Peterburg: ELBI; 2007. 179 p.

30. Jacobson J.L. and Jacobson S.W. Intellectual impairment in children exposed to polychlorinated biphenyls in utero. $N$. Engl. J. Med. 2006; 335: 783-789.

31. Jarrell J., Villenenve D., Franklin C. et al. Contamination of human ovarian follicular fluid and serum by chlorinated organic compounds in three Canadian cities. J. Can. Med. Assoc. 2003; 148: 1321-1327.

32. Dolgikh O.V., Krivtsov A.V., Lykhina T.S. Osobennosti immunnogo i geneticheskogo statusa u zhenshchin v usloviyakh proizvodstva(Features of immune and genetic status in women under conditions of production) [in Russian]. Rossiiskiiimmunol ogicheskiizhurnal. 2012; 2(1): 50-52. 
33. Common Menstrual Problems among Slum Adolescent Girls of Western Maharashtra, India/ Ganganahalli P and et. al. Journal of Krishna Institute of Medical Sciences University. 2013; 02: 89-97.

34. Serov V.N., Kozhin A.A. Ekologo-generativnyi dissonans i patofiziologicheskie aspekty narushenii generativnoi funktsii tsentral'

35. nogo geneza. Akusherstvo i ginekologiya (Ecological-generative dissonance and pathophysiological aspects of violations of the generative function of central genesis. obstetrics and gynecology)[in Russian]. 2005; 8: 12-15.

36. Andreeva G.F., Ragimova O.A., Zhukova E.I. Poroki razvitiya novorozhdennykh v Saratovskoi populyatsii. Vliyanie antropogennykh faktorov na strukturnye preobrazovaniya kletok, tkanei i organov cheloveka i zhivotnykh (The influence of anthropogenic factors on structural transformations of human cells, tissues and organs)[in Russian]. Volgograd. 2005. 7-8 p.

37. Irgasheva S.U. Chastota i struktura narushenii polovogo razvitiya u devochek-podrostkovRespubliki Uzbekistan (The frequency and structure of violations and sexual development in adolescent girls in the Republic of Uzbekistan)[in Russian].Tsentral'noaziatskiinauchno-prakticheskiizhurnal. 2008; 3: 35-37.

38. Gusev A.A. Problemyekologo-ekonomicheskoibezopasnosti v Kurskoioblasti (Problems of ecological and economic security in the Kursk region) [in Russian]. Mediko-ekologicheskieInformatsionnyetekhnologii. 2004. 64-66 p.

39. 38. Ostanin A.A. idr. Rol' tsitokinov v regulyatsi I sozrevaniyaootsitov. Tsitokinyivospalenie (The role of cytokines in regulating the maturation of oocytes) [in Russian]. 2005; 2: 86-87.

40. Bukovsky A. Oogenesis from human somatic stem cells and a role of immune adaptation in premature ovarian failure [in Russian]. Curr Stem Cell Res Ther; 2006; 3: 289-303.

41. Ho Y., Wigglesworth K., Eppig J.J., and Shultz R.M. Preimplantation development of mouse embryos in KSOM: augmentation by amino acids and analysis of gene expression. Mol. Reprod. Dev. 2005; 41: 232-238.

42. Cohn B.A., Wolff M.S., and Cirillo P.M. DDT and breast cancer in young women. Environ. Health Persp. 2007 ; $115: 1406-1414$.

43. Upson K., De Roos A.J., Thompson M.L., Sathyanarayana S., Scholes D., Barr D.B., Holt V.L. Organochlorinepesticides and risk of endometriosis: findings from a population-based case-control study. Environ HealthPerspect. 2013;121: 1319-24.

44. Snijder C.A., teVelde E., Roeleveld N., Burdorf A. Occupational exposure to chemical substances and time to pregnancy: a systematic review. Hum Reprod Update. 2012;18: 284-300.

45. Wohlfahrt-Veje C., Main K.M., Schmidt I.M., Boas M., Jensen T.K., Grandjean P., Skakkebæk N.E., Andersen H.R. Lower birth weight and increased body fat at school age in children prenatally exposed to modern pesticides: a prospective study. Environ Health. 2011; 20: 10-79.

46. Jørgensen A., Nellemann Ch., Wohlfahrt-Veje Ch., Kold Jensen T., Katharina M. Main, HelleRaun Andersen. Interaction between paraoxonase 1 polymorphism and prenatal pesticide exposure on metabolic markers in children using a multiplex approach. Reproductive toxicology. 2015; 51: 22-30.

47. Koutroulakis D., Sifakis S., Tzatzarakis M.N., Alegakis A.K., Theodoropoulou E., Kavvalakis M.P., Kappou D., et al. phosphates in amniotic fluid as a biomarker of fetal exposure to organophosphates in Crete, Greece; association with fetal growth. Reproductive toxicology. 2014; 46: 98-105.

48. Gladen B.C., Klebanoff M.A., Hediger M.L., Katz S.H., Barr D.B., Davis M.D., et al. Prenatal DDT exposure in relation to anthropometric and pubertal measures in adolescent males. Environ Health Perspect. 2004; 112: 1761-1767.

49. Deng F., Tao F.B., Liu D.Y., Xu Y.Y., Hao J.H., Sun Y., et al. Effects of growth environments and two environmental endocrine disruptors on children with idiopathic precocious puberty. Eur J Endocrinol. 2012; 166: 803-809.

50. Ouyang F., Perry M.J., Venners S.A., Chen C., Wang B., Yang F., et al. Serum DDT, age at menarche and abnormal menstrual cycle length. Occup Environ Med. 2005; 62: 878-84.

51. Vasiliu O., Muttineni J., Karmaus W. In utero exposure to organochlorines and age at menarche. Hum Reprod. 2004; 19: 1506-12.

52. Vasiliu O., Muttineni J., Karmaus W. In utero exposure to organochlorines and age at menarche. Hum Reprod. 2004;19(7): 150612.

53. John D. Meeker, ScD Exposure to Environmental Endocrine Disruptors and Child Development. Arch PediatrAdolesc Med. 2012; 166(10): 952-958.

54. Michael E. Baker and Gary Hardiman Transcriptional analysis of endocrine disruption using zebrafish and massively parallel sequencing. J MolEndocrinol. 2014. Vol. 52, №3. 241-256 p. doi:10.1530/JME-13-0219.

55. Denham M., Schell L.M., Deane G., Gallo M.V., Ravenscroft J., DeCaprioA.P. Relationship of lead, mercury, mirex, dichlorodi phenyldichloroethylene, hexachlorobenzene, and polychlorinated biphenyls to timing of menarche among Akwesasne Mohawk girls. Pediatrics. 2005;115: 127-134.

56. Perry M.J., Ouyang F., Korrick S.A., Venners S.A., Chen C., Xu X., Lasley B.L., Wang X. A prospective study of serum DDT and progesterone and estrogen levels across the menstrual cycle in nulliparous women of reproductive age. Am J Epidemiol. 2006; 164 (11): 1056-64. 